\title{
Regrowth of willow shoots in the second 4-year rotation at various fertilization with nitrogen
}

\author{
Diana Fijałkowska ${ }^{1, *}$, and Leszek Styszko \\ ${ }^{1}$ Koszalin University of Technology, Faculty of Civil Engineering, Environmental and Geodetic \\ Sciences, Sniadeckich 2, 75-452 Koszalin, Poland
}

\begin{abstract}
The aim of the experiment was to assess the dynamics of regrowth of shoots of 10 genotypes of basket willow (Salix viminalis L.) in the second 4-year rotation, cultivated on sandy soil in the Middle Pomerania $\left(16^{\circ} 24^{\prime} \mathrm{N}\right.$ and $\left.54^{\circ} 08^{\prime} \mathrm{E}\right)$ under various fertilization with nitrogen $\left(0,60,120\right.$ and $\left.180 \mathrm{~kg} \mathrm{~N} \cdot \mathrm{ha}^{-1}\right)$ and under rainfall-retention water system. The field experiment was established in 2007 using method of randomized sub-blocks in a subsidiary system with four replications, where on large plots four doses of nitrogen were drawn, and within doses - 10 genotypes of willow. In 2012-2015 the dynamics of regrowth of willow shoots in four separate dates for the first and second row of plot separately were evaluated. During first rotation (2008-2011) in the first row of plot shoots were mowed 2-times (after third and first year of regrowth), and the second row - once (after fourth year of regrowth). During the second 4-year rotation of the biggest variability in relation to the height and thickness of willow shoots and the number of live and dead shoots in snag was noted between years of shoots regrowth and for the amount of live and dead snags on the plot - between the frequencies of mowing.
\end{abstract}

\section{Introduction}

The biomass harvested for energy purposes is a significant source of renewable energy in Poland and in Europe $[1,2]$. Its consumption in Polish power industry increased from $9641 \mathrm{t}$ to $65,470 \mathrm{t}$ in the years 2005-2011 [3]. Big quantities of biomass for heating are used by households [2]. On intensive field cultivations, during 3-year rotations, growth of wood is sometimes up to 10 times higher than in the forests [4]. Growths of willow biomass depend on adaptation of cultivation of willow genotypes to natural conditions (soil, water and thermal) where plantation is located, including a system of organic and mineral fertilization and irrigation [5]. In Sweden, about 50\% of the willow cultivations is fertilized with municipal wastewater, and on the other objects mineral fertilization with dose of approx. $100 \mathrm{~kg} \mathrm{~N} \cdot \mathrm{ha}^{-1}$ is used. In Canada it is recommended to apply fertilization equivalent to $100-150 \mathrm{~kg} \mathrm{~N} \cdot \mathrm{ha}^{-1}$ taking into account also organic fertilization [6]. Most nitrogen is taken by willow in the period from April to October, and most intensively - from May to July [7]. Efficiency of use of nutrient elements is higher in longer production cycles than in one year cycle $[8,9]$. It has been reported in the literature that during the

*Corresponding author: fijalkowska@,wilsig.tu.koszalin.pl 
second cycle of cultivation shoots biomass yields are higher than during the first $[10,11]$. Willow clones vary in pace of achieving maximum production potential and its increase depends on the dose of fertilizer. Swedish and US experiments prove that the optimal willow biomass yield is obtained during cultivation in 3-6 year harvest cycle depending on the clone, habitat conditions, fertilization and meteorological conditions [12]. The most important factor limiting the growth of willows in Sweden and across temperate regions are, apart from water, nutrients, mainly nitrogen [13].

Research concerning dynamics of willow biomass growth during years of cultivation were carried out in Poland mostly in the first 3-4 year rotation [14, 15-19]. Such measurements may be used for prediction of willow biomass yield [16].

The aim of the experiment was to assess the dynamics of regrowth of shoots of 10 genotypes of basket willow (Salix viminalis L.) in the second 4-year rotation, cultivated on light soil in the Middle Pomerania under various fertilization with nitrogen $(0,60,120$ and $180 \mathrm{~kg} \mathrm{~N} \cdot \mathrm{ha}^{-1}$ ) and under rainfall-retention water system.

\section{Materials and methods}

Measurements of height and thickness of willow shoots, the number of living and dead stems in snag and quantities of live snags on the plot were conducted on a field experiment carried out in 2012-2015 on the experimental field of Technical University of Koszalin in Kościernica $\left(16^{\circ} 24^{\prime} \mathrm{N}\right.$ and $\left.54^{\circ} 08^{\prime} \mathrm{E}\right)$. The soil under the experiment was light, of quality class RIVa-IVb, of good rye complex, appropriate podsolic - pseudopodsolic with composition of light loamy sand - to the depth of $100 \mathrm{~cm}$, and of light loam - deeper. The content of humus in the layer $0-30 \mathrm{~cm}$ of soil was $1.41 \%$. The experiment was established in 2007. The first 4-year cycle of shoots regrowth was in 2008-2011, and the second - in 2012-2015. As part of the experiment, within large plots, four doses of mineral nitrogen were drawn: (a) $0 \mathrm{~kg} \mathrm{~N} \cdot \mathrm{ha}^{-1}$, (b) $60 \mathrm{~kg} \mathrm{~N} \cdot \mathrm{ha}^{-1}$, (c) $120 \mathrm{~kg} \mathrm{~N} \cdot \mathrm{ha}^{-1}$ and (d) $180 \mathrm{~kg} \mathrm{~N} \cdot \mathrm{ha}^{-1}$, and within doses of nitrogen, 10 genotypes of basket willow (Salix viminalis L.): 1047, 1054, 1047D, Start, Sprint, Turbo, Ekotur, Olof, Jorr i Tordis. Nitrogen fertilization was applied according to experiment design, each year in April. In 2007, on the plot of $25.3 \mathrm{~m}^{2}$ of area, in two rows 56 willow cuttings were planted per row, that is 22,134 pcs. per ha. In the first 4-years rotation the first row was mowed twice (after 3 years and after one year of regrowth), and the second row - once (after four years of regrowth). For examined factors standard analysis of variance was conducted and structure of variance components was determined, and significance of the effects was assessed with F test. Data on the weather pattern representative for Kościernica region were obtained from the meteorological station in Koszalin (Table 1). Annual rainfall in Koszalin was from $831.9 \mathrm{~mm}$ in 2012 to $588.9 \mathrm{~mm}$ in 2014, and during willow vegetation - from $536.6 \mathrm{~mm}$ in 2012 to $387.0 \mathrm{~mm}$ in 2014 . Extreme hydrothermal conditions (extremely dry and very dry and very wet and extremely wet) indicated by Sielianinow coefficient $(\mathrm{K})$ fall within the ranges $<0.7$ and $>2.5$. During vegetation period this coefficient ranged from 1.87 in 2012 to 1.34 in 2013 and 2014. Extremely dry and very dry conditions $(\mathrm{K}<0.7)$ occurred in May 2012, July 2014 and August 2015, and very wet $(\mathrm{K}>2.5)$ occurred in April 2014, June 2015 and September 2012. 
Table 1. Rainfall [mm] and Sielianinow hydrothermal coefficient in Koszalin in the years 2012-2016 according to Institute of Meteorology and Water Management.

\begin{tabular}{|c|c|c|c|c|c|c|c|c|}
\hline \multirow{2}{*}{ Month } & \multicolumn{4}{|c|}{ Annual rainfall } & \multicolumn{4}{c|}{$\begin{array}{c}\text { Sielianinow coefficient (K) } \\
\text { in the years }\end{array}$} \\
\cline { 2 - 9 } & 2012 & 2013 & 2014 & 2015 & 2012 & 2013 & 2014 & 2015 \\
\hline I-III & 175.9 & 128.7 & 84.5 & 100.3 & - & - & - & - \\
\hline IV & 39.1 & 42.2 & 72.1 & 18.4 & 1.92 & 2.07 & 2.50 & 0.83 \\
\hline V & 15.8 & 51.1 & 52.5 & 37.3 & 0.37 & 1.19 & 1.37 & 1.06 \\
\hline VI & 88.6 & 64.4 & 55.9 & 144.7 & 1.88 & 1.37 & 1.23 & 3.42 \\
\hline VII & 119.4 & 54.5 & 37.9 & 96.3 & 2.14 & 0.98 & 0.59 & 1.79 \\
\hline VIII & 99.8 & 52.3 & 83.6 & 13.3 & 1.78 & 0.93 & 1.56 & 0.21 \\
\hline IX & 102.5 & 85.4 & 54.4 & 67.1 & 2.65 & 2.21 & 1.19 & 1.56 \\
\hline X & 71.4 & 44.3 & 30.6 & 28.5 & 2.19 & 1.36 & 0.88 & 1.09 \\
\hline IV-X & 536.6 & 394.2 & 387.0 & 405.6 & 1.87 & 1.34 & 1.34 & 1.42 \\
\hline
\end{tabular}

\section{Results and discussion}

Factors used in the experiment (willow genotypes, nitrogen dose, dates of measurements and years of shoots regrowth) had significant impact on the variability of analyzed features (Table 2).

Table 2. Impact of examined factors on the structure of variance components in analyses of features.

\begin{tabular}{|c|c|c|c|c|c|c|}
\hline \multirow{3}{*}{$\begin{array}{c}\text { Variance } \\
\text { component }^{1}\end{array}$} & \multirow{3}{*}{$\begin{array}{l}\text { Number } \\
\text { of levels }\end{array}$} & \multicolumn{5}{|c|}{ Percentage structure of variance components in analyses } \\
\hline & & \multicolumn{2}{|c|}{ shoots } & \multicolumn{2}{|c|}{ shoots in snag } & \multirow{2}{*}{$\begin{array}{l}\text { live snags } \\
\text { on the plot }\end{array}$} \\
\hline & & height & thickness & live & dead & \\
\hline $\mathrm{E}$ & 10 & $3.7 * * *$ & $5.5 * * *$ & $1.6^{* * *}$ & $1.1 * * *$ & $6.2 * * *$ \\
\hline $\mathrm{D}$ & 4 & $0.7 * * *$ & $0.9 * * *$ & $1.0 * * *$ & $0.4 * * *$ & $9.0 * * *$ \\
\hline $\mathrm{C}$ & 4 & $4.8^{* * *}$ & $3.7 * * *$ & $2.4 * * *$ & $2.3 * * *$ & $0.1 * * *$ \\
\hline $\mathrm{B}$ & 2 & $4.5^{* * *}$ & $6.8 * * *$ & $15.4 * * *$ & $3.1 * * *$ & $21.0 * * *$ \\
\hline $\mathrm{A}$ & 4 & $73.7 * * *$ & $68.0 * * *$ & $18.6^{* * *}$ & $55.2 * * *$ & $2.2 * * *$ \\
\hline Sum (A-E) & & 87.4 & 84.9 & 39.0 & 62.1 & 38.5 \\
\hline ExD & & $0.9 * * *$ & $1.4 * * *$ & $1.5 * * *$ & $1.4 * * *$ & $5.1 * * *$ \\
\hline ExC & & $0.2 * * *$ & $0.3 * * *$ & $0.2 * * *$ & $0.1^{*}$ & 0.0 \\
\hline $\mathrm{DxC}$ & & 0.0 & $0.3 * * *$ & $0.8 * *$ & $1.4 * * *$ & $0.6^{* * *}$ \\
\hline ExB & & $0.6^{* * * *}$ & $0.8 * * *$ & $3.0 * * *$ & $1.6^{* * *}$ & $15.4 * * *$ \\
\hline DxB & & $0.3 * * *$ & $0.1 * * *$ & $1.3 * * *$ & $1.0 * * *$ & $12.2^{* * *}$ \\
\hline $\mathrm{CxB}$ & & $0.1 * * *$ & $0.1 * * *$ & $0.3 * * *$ & $0.2 * * *$ & 0.0 \\
\hline ExA & & $1.2 * * *$ & $1.6 * * *$ & $2.8 * * *$ & $1.3 * * *$ & $0.9 * * *$ \\
\hline DxA & & $1.0 * * *$ & $1.2 * * *$ & $0.6 * * *$ & $4.0 * * *$ & $0.4 * * *$ \\
\hline $\mathrm{CxA}$ & & $1.7 * * *$ & $0.8^{* * *}$ & $7.5 * * *$ & $2.2 * * *$ & $0.1 * * *$ \\
\hline $\mathrm{BxA}$ & & $0.1 * * *$ & $0.1 * * *$ & $20.4 * * *$ & $2.3 * * *$ & $0.1 * * *$ \\
\hline $\begin{array}{c}\text { Other } \\
\text { interactions }\end{array}$ & & 6.5 & 8.4 & 22.6 & 22.4 & 26.7 \\
\hline $\begin{array}{c}\text { Sum of } \\
\text { interactions }\end{array}$ & & 12.6 & 15.1 & 61.0 & 37.9 & 61.5 \\
\hline
\end{tabular}

${ }^{\mathrm{T}}$ Designation of variance components and significance levels are given in Table 3

Variability caused by their actions ranged from $87.4 \%$ for the height of shoots to $38.5 \%$ for live snags on the plot. Particularly big effects were obtained for interactions: BxA 
(20.4\%) for live shoots in snag and ExB and DxB for the live and the dead snags on the plot.

Table 3 presents results of biometric measurements of will in the years 2012-2015, and Table 4, differences between the extreme values and their relative reference to an average from experiment within tested feature. The data given in Table 4 confirm that the parameters of willow canopy architecture characterized by height and thickness of shoots and number of live and dead shoots in snag the biggest differences were caused by years of shoots regrowth (respectively : 122.5\%, 117.8\%, 77.6\% and 152.5\%) and the lowest - dose of nitrogen (respectively: $8.9 \%$. 12.8\%, 17.4\% and $14.2 \%$ ).

Table 3. Impact of examined factors on results of willow biometric measusremnts.

\begin{tabular}{|c|c|c|c|c|c|c|}
\hline \multirow{2}{*}{\multicolumn{2}{|c|}{ Examined factors }} & \multicolumn{5}{|c|}{ Designation of analyses } \\
\hline & & \multicolumn{2}{|c|}{ shoots } & \multicolumn{2}{|c|}{ shoots in snags } & \multirow{2}{*}{$\begin{array}{c}\text { live snags } \\
\text { on the plot } \\
\text { [pcs.] }\end{array}$} \\
\hline Factors & level & $\begin{array}{l}\text { height } \\
{[\mathrm{cm}]}\end{array}$ & $\begin{array}{c}\text { thickness } \\
{[\mathrm{mm}]}\end{array}$ & $\begin{array}{c}\text { live } \\
\text { [pcs.] }\end{array}$ & $\begin{array}{c}\text { dead } \\
\text { [pcs.] }\end{array}$ & \\
\hline \multirow{5}{*}{$\begin{array}{c}\text { Years of shoots } \\
\text { regrowth [A] }\end{array}$} & 1 & 97.2 & 6.5 & 9.95 & 0.47 & 22.2 \\
\hline & 2 & 240.6 & 14.8 & 6.08 & 1.44 & 21.2 \\
\hline & 3 & 387.5 & 23.0 & 4.78 & 2.66 & 20.5 \\
\hline & 4 & 460.2 & 27.7 & 4.95 & 3.58 & 18.8 \\
\hline & $\mathrm{NIR}_{0.05}$ & $2.9 * * *$ & $0.2 * * *$ & $0.15 * * *$ & $0.06^{* * *}$ & $0.2 * * *$ \\
\hline \multirow{3}{*}{$\begin{array}{c}\text { Variant of } \\
\text { shoots mowing } \\
{[\mathrm{B}]} \\
\end{array}$} & $\mathrm{I}$ & 268.3 & 15.9 & 4.89 & 1.81 & 17.5 \\
\hline & II & 324.5 & 20.1 & 7.99 & 2.26 & 23.8 \\
\hline & $\mathrm{NIR}_{0.05}$ & $2.0 * * *$ & $0.1 * * *$ & $0.11 * * *$ & $0.04 * * *$ & $0.1 * * *$ \\
\hline \multirow{5}{*}{$\begin{array}{c}\text { Dates of } \\
\text { measurements } \\
{[\mathrm{C}]}\end{array}$} & $31 \mathrm{~V}$ & 248.3 & 15.4 & 7.36 & 1.81 & 20.9 \\
\hline & $30 \mathrm{VI}$ & 276.4 & 17.1 & 6.97 & 1.81 & 20.8 \\
\hline & $30 \mathrm{IX}$ & 323.4 & 19.3 & 5.91 & 2.12 & 20.6 \\
\hline & $10 \mathrm{XI}$ & 337.4 & 20.3 & 5.51 & 2.40 & 20.4 \\
\hline & $\mathrm{NIR}_{0.05}$ & $2.9 * * *$ & $0.2 * * *$ & $0.15 * * *$ & $0.06^{* * *}$ & $0.2 * * *$ \\
\hline \multirow{5}{*}{$\begin{array}{c}\text { Doses of } \\
\text { nitrogen } \\
\text { in } \mathrm{kg} \mathrm{N} \cdot \mathrm{ha}^{-1}[\mathrm{D}]\end{array}$} & 0 & 277.5 & 16.6 & 6.90 & 2.00 & 23.6 \\
\hline & 60 & 313.5 & 18.7 & 6.89 & 2.20 & 22.1 \\
\hline & 120 & 290.7 & 17.8 & 6.19 & 1.91 & 20.2 \\
\hline & 180 & 303.9 & 18.9 & 5.78 & 2.03 & 16.8 \\
\hline & $\mathrm{NIR}_{0.05}$ & $2.9 * * *$ & $0.2 * * *$ & $0.15 * * *$ & $0.06 * * *$ & $0.2 * * *$ \\
\hline \multirow{11}{*}{$\begin{array}{c}\text { Willow } \\
\text { genotype [E] }\end{array}$} & 1047 & 280.5 & 17.1 & 7.23 & 2.26 & 21.8 \\
\hline & 1054 & 278.2 & 16.8 & 6.44 & 2.01 & 20.1 \\
\hline & $1047 \mathrm{D}$ & 294.0 & 17.9 & 7.30 & 2.04 & 19.2 \\
\hline & Start & 244.0 & 14.4 & 5.12 & 1.81 & 15.8 \\
\hline & Sprint & 275.4 & 16.2 & 6.23 & 2.17 & 18.8 \\
\hline & Turbo & 277.6 & 16.5 & 6.45 & 1.74 & 21.5 \\
\hline & Ekotur & 354.0 & 22.7 & 6.90 & 2.10 & 24.7 \\
\hline & Olof & 316.9 & 19.4 & 5.43 & 1.82 & 20.4 \\
\hline & Jorr & 289.8 & 17.2 & 6.89 & 2.08 & 21.3 \\
\hline & Tordis & 356.4 & 22.2 & 6.40 & 2.31 & 23.1 \\
\hline & $\mathrm{NIR}_{0.05}$ & $4.6 * * *$ & $0.3 * * *$ & $0.24 * * *$ & $0.10 * * *$ & $0.2 * * *$ \\
\hline \multicolumn{2}{|c|}{ Average } & 296.3 & 18.0 & 6.44 & 2.04 & 20.7 \\
\hline
\end{tabular}

Significance at level: ${ }^{*} \alpha=0.05 ;{ }^{* *} \alpha=0.01 ;{ }^{* * *} \alpha=0.001$ 
Table 4. Variability of examined factors and their relative reference to an average from experiment.

\begin{tabular}{|c|c|c|c|c|c|c|}
\hline \multirow{2}{*}{\multicolumn{2}{|c|}{ Main factors of the experiment }} & \multicolumn{5}{|c|}{ Designation of analyses } \\
\hline & & \multicolumn{2}{|c|}{ shoots } & \multicolumn{2}{|c|}{ shoots in snags } & \multirow{2}{*}{$\begin{array}{l}\text { live snags } \\
\text { on the } \\
\text { plot [pcs.] }\end{array}$} \\
\hline Factors $^{1}$ & $\begin{array}{l}\text { Difference between } \\
\text { extreme values }\end{array}$ & $\begin{array}{l}\text { height } \\
{[\mathrm{cm}]}\end{array}$ & $\begin{array}{l}\text { thickness } \\
{[\mathrm{mm}]}\end{array}$ & $\begin{array}{l}\text { live } \\
\text { [pcs.] }\end{array}$ & $\begin{array}{c}\text { dead } \\
\text { [pcs.] }\end{array}$ & \\
\hline \multirow{2}{*}{ A } & difference & 363 & 21.2 & 5.00 & 3.11 & 3.4 \\
\hline & percent & 122.5 & 117.8 & 77.6 & 152.5 & 16.4 \\
\hline \multirow{2}{*}{ B } & difference & 56.2 & 4.2 & 3.1 & 0.45 & 6.3 \\
\hline & percent & 19.0 & 23.3 & 48.1 & 22.1 & 30.4 \\
\hline \multirow{2}{*}{$\mathrm{C}$} & difference & 89.1 & 4.9 & 1.85 & 0.59 & 0.5 \\
\hline & percent & 30.1 & 27.2 & 28.7 & 28.9 & 2.4 \\
\hline \multirow{2}{*}{$\mathrm{D}$} & difference & 26.4 & 2.3 & 1.12 & 0.29 & 6.8 \\
\hline & percent & 8.9 & 12.8 & 17.4 & 14.2 & 32.9 \\
\hline \multirow{2}{*}{$\mathrm{E}$} & difference & 112.4 & 8.3 & 2.11 & 0.57 & 8.9 \\
\hline & percent & 37.9 & 46.1 & 32.8 & 27.9 & 43.0 \\
\hline \multirow{2}{*}{$\begin{array}{l}\text { Average } \\
\text { from } \\
\text { experiment }\end{array}$} & difference & 296.3 & 18.0 & 6.44 & 2.04 & 20.7 \\
\hline & percent & 100.0 & 100.0 & 100.0 & 100.0 & 100.0 \\
\hline
\end{tabular}

${ }^{1}$ Designation of experiment main components are given in Table 3

Impact of studied factors was different for live snags on the plot: the biggest differences caused willow genotypes (43.0\%), slightly lower - dose of nitrogen (32.9\%) and variants of shoots mowing (30.4\%), small - years of shoots regrowth $(16.4 \%)$, and the smallest - dates of measurements during vegetation $(2.4 \%)$.

Table 5 presents data for interaction of variants of willow mowing with doses of nitrogen. The biggest differences between variant II and I of shoots mowing for all studied factors were at dose of nitrogen of $180 \mathrm{~kg} \mathrm{~N} \cdot \mathrm{ha}^{-1}$, and the smallest - for height and thickness of shoots at dose of $60 \mathrm{~kg} \mathrm{~N} \cdot \mathrm{ha}^{-1}$, and for other features - on control objects $\left(0 \mathrm{~kg} \mathrm{~N} \cdot \mathrm{ha}^{-1}\right)$.

Table 5. Impact of interaction between variants of willow mowing and doses of nitrogen on parameters of willow canopy architecture.

\begin{tabular}{|c|c|r|r|r|r|r|}
\hline $\begin{array}{c}\text { Nitrogen } \\
\text { dose } \\
{\left[\mathrm{kg} \mathrm{N} \cdot \mathrm{ha}^{-1}\right]}\end{array}$ & $\begin{array}{c}\text { Mowing } \\
\text { variant }^{2}\end{array}$ & $\begin{array}{c}\text { Shoots } \\
\text { height }[\mathrm{cm}]\end{array}$ & $\begin{array}{c}\text { Shoots } \\
\text { thickness } \\
{[\mathrm{mm}]}\end{array}$ & $\begin{array}{c}\text { Live shoots } \\
\text { in snag } \\
\text { [pcs.] }\end{array}$ & $\begin{array}{c}\text { Dead } \\
\text { shoots in } \\
\text { snag [pcs.] }\end{array}$ & $\begin{array}{c}\text { Live snags } \\
\text { on the plot } \\
\text { [pcs.] }\end{array}$ \\
\hline \multirow{2}{*}{0} & I & 250.8 & 14.7 & 5.93 & 1.87 & 22.9 \\
\cline { 2 - 7 } & II & 304.2 & 18.6 & 7.86 & 2.12 & 24.4 \\
\hline \multirow{2}{*}{60} & I & 291.5 & 16.8 & 5.40 & 2.03 & 20.0 \\
\cline { 2 - 7 } & II & 335.5 & 20.6 & 8.38 & 2.38 & 24.1 \\
\hline \multirow{2}{*}{120} & I & 263.9 & 15.8 & 4.50 & 1.71 & 16.6 \\
\cline { 2 - 7 } & II & 317.4 & 19.8 & 7.87 & 2.11 & 23.8 \\
\hline \multirow{2}{*}{180} & I & 267.0 & 16.4 & 3.71 & 1.61 & 10.5 \\
\cline { 2 - 7 } & II & 340.8 & 21.5 & 7.85 & 2.45 & 23.2 \\
\hline \multicolumn{2}{|r}{$\mathrm{NIR}_{0.05}$} & $4.1 * * *$ & $0.3 * * *$ & $0.21 * * *$ & $0.09 * * *$ & $0.2 * * *$ \\
\hline
\end{tabular}

${ }^{2}$ Mowing variant: I - mowing after 3-year and 1-year regrowth, II - mowing after 4-year regrowth

Table 6 presents data concerning interaction between variants of willow mowing and willow genotypes. The biggest differences between variant II and I of shoots mowing for height and thickness of shoots were on plots of 1047 clone, and the lowest - for Ekotur variety. When taking into account live and dead shoots in snag the biggest differences were for Sprint variety, and the lowest, respectively for Olof and Ekotur varieties. At live willow 
snags on the plot, Start variety responded strongest to variants of mowing, and Ekotur and Olof varieties had no reaction to variants of mowing.

Table 6. Impact of interaction between variants of shoots mowing and willow genotypes on parameters of willow canopy architecture.

\begin{tabular}{|c|c|c|c|c|c|c|}
\hline $\begin{array}{l}\text { Willow } \\
\text { genotype }\end{array}$ & $\begin{array}{l}\text { Mowing } \\
\text { variant }^{2}\end{array}$ & $\begin{array}{c}\text { Shoots } \\
\text { height }[\mathrm{cm}]\end{array}$ & $\begin{array}{c}\text { Shoots } \\
\text { thickness } \\
{[\mathrm{mm}]}\end{array}$ & $\begin{array}{l}\text { Live shoots } \\
\text { in snag } \\
\text { [pcs.] }\end{array}$ & $\begin{array}{c}\text { Dead } \\
\text { shoots in } \\
\text { snag [pcs.] }\end{array}$ & $\begin{array}{l}\text { Live snags } \\
\text { on the plot } \\
\text { [pcs.] }\end{array}$ \\
\hline \multirow{2}{*}{1047} & I & 239.1 & 14.1 & 5.58 & 2.12 & 17.8 \\
\hline & II & 322.0 & 20.1 & 8.89 & 2.40 & 25.8 \\
\hline \multirow{2}{*}{1054} & I & 251.6 & 14.6 & 4.36 & 1.70 & 15.5 \\
\hline & II & 304.8 & 19.0 & 8.53 & 2.32 & 24.8 \\
\hline \multirow{2}{*}{ 1047D } & I & 260.3 & 15.7 & 5.25 & 1.64 & 15.4 \\
\hline & II & 327.6 & 20.0 & 9.36 & 2.44 & 23.0 \\
\hline \multirow{2}{*}{ Start } & $\mathrm{I}$ & 209.2 & 12.0 & 2.96 & 1.52 & 8.7 \\
\hline & II & 278.9 & 16.8 & 7.28 & 2.10 & 22.9 \\
\hline \multirow{2}{*}{ Sprint } & $\mathrm{I}$ & 239.6 & 13.7 & 3.87 & 1.64 & 11.9 \\
\hline & II & 305.2 & 18.7 & 8.59 & 2.71 & 25.8 \\
\hline \multirow{2}{*}{ Turbo } & $\mathrm{I}$ & 240.1 & 13.8 & 4.89 & 1.53 & 19.1 \\
\hline & II & 315.1 & 19.1 & 8.01 & 1.96 & 24.0 \\
\hline \multirow{2}{*}{ Ekotur } & I & 339.9 & 22.0 & 6.24 & 2.15 & 25.1 \\
\hline & II & 368.1 & 23.5 & 7.55 & 2.05 & 24.3 \\
\hline \multirow{2}{*}{ Olof } & I & 300.0 & 17.7 & 5.18 & 1.77 & 20.9 \\
\hline & II & 333.7 & 21.1 & 5.69 & 1.88 & 19.8 \\
\hline \multirow{2}{*}{ Jorr } & I & 257.0 & 14.7 & 5.28 & 1.90 & 18.2 \\
\hline & II & 322.6 & 19.7 & 8.50 & 2.26 & 24.4 \\
\hline \multirow{2}{*}{ Tordis } & I & 346.0 & 21.1 & 5.26 & 2.11 & 22.5 \\
\hline & II & 366.9 & 23.2 & 7.55 & 2.51 & 23.7 \\
\hline \multicolumn{2}{|c|}{$\mathrm{NIR}_{0.05}$} & $6.5 * * *$ & $0.4^{* * * *}$ & $0.34 * * *$ & $0.14 * * *$ & $0.3 * * *$ \\
\hline
\end{tabular}

${ }^{2}$ Mowing variant: I - mowing after 3-year and 1-year regrowth, II - mowing after 4-year regrowth

Own study showed that during the multi-year willow cultivation there are changes in the canopy architecture resulting from the impact of years of shoots regrowth, mowing pattern, fertilization with mineral nitrogen and varietal characteristics of willow. In Polish literature such effects are documented in reference to the first 2-, 3- or 4-year rotation, but still there are no such analyses for subsequent rotations [4, 14-18, 20-22]. The foreign literature reports that, in further rotations higher willow biomass yield is obtained than in the first $[10,11]$. Styszko i Fijałkowska [21] have also proven that negative impact of follow-up fertilization of willow with compost an mineral nitrogen on shoots regrowth in height and thickness and on number of live shoots in snag and live snags on the plot is expected.

Measurements of dynamics of willow shoots increase during vegetation may be used for predicting biomass yield. Prognostic equations of an average yield of fresh biomass of 9 willow clones, acquired from light soil, fertilized with compost from municipal sewage sludge and various nitrogen doses $\left(0,90\right.$ and $\left.180 \mathrm{~kg} \mathrm{~N} \cdot \mathrm{ha}^{-1}\right)$ have been developed by the authors in previous work [16]. Equations include data from biometric measurements: length and thickness of shoots and number of shoots in snag from four dates of measurements and interaction of length and thickness of shoots. Those analyzes showed that incorporation of additional data relating to the weather pattern allows prediction of yield of fresh biomass of shoots with high precision (about $4.7 \%$ ) during each year of cultivation. There are no similar analyses in the literature for the varieties and clones of willow fertilized with mineral nitrogen. 


\section{Conclusions}

1. Number of years of shoots regrowth, variants of shoots mowing, dose of nitrogen fertilization and willow genotype affect canopy architecture in the second 4-year rotation assessed with length and thickness of shoots, number of live and dead shoots in snag and number of live snags on the plot.

2. Willow genotypes vary in response to years of cultivation, fertilization with mineral nitrogen and variants of mowing in the dynamics of shoots increase in length and thickness, the number of live and dead shoots in snag and number of live snags on the plot.

3. Increased fertilization with mineral nitrogen enhances growth of willow shoots in length and thickness, but reduces the number of live shoots in snag and the number of live snags on the plot.

4. Impact of willow mowing variant on growth of willow shoots in length and thickness, number of live shoots in snag and number of live snags on the plot is more visible at high than at low fertilization with mineral nitrogen.

The authors would like to thank the Lillohus AB company; 29161 Kristianstad in Sweden for gratuitous transfer to Olof, Jorre and Tordis varieties and Mr. Przemysław Dobrzaniecki from Agrobränsle AB in Poznan for intermediation in this donation.

\section{References}

1. EurObserv'ER, $15^{\text {th }}$ EurObserv'ER Report, 103 (2015)

2. GUS, Energia ze źródel odnawialnych $w$ Polsce $w 2015$ r. (GUS Warszawa, 2016)

3. Z. Grudziński, ROCZ OCHR SR 15, 2249-2266 (2013)

4. M. Stolarski, S. Szczukowski, J. Tworkowski, Fragm. Agron. 19(2), 39-51 (2002)

5. M. Stolarski, S. Szczukowski, J. Tworkowski, [In:] Biomasa dla elektroenergetyki i cieptownictwa - Szanse i problemy. Wyd. Wieś Jutra Warszawa, 93-99 (2007)

6. W. Guidi, F.E. Pitre, M. Labresque, Biomass Now - Suistainnable Growth and Use. INTECH: 421-448. http://dx.doc.org./10.5772/51111 (2013)

7. M. Labrecque, T. Teodorescu, FOREST ECOL MANAG 150, 223-239, (2001)

8. H. Adegbidi, T.A. Volk, E.H. White, L.P. Abrahamson, R.D. Briggs, D.H. Bickelhaupt, BIOMASS BIOENERG 20, 399-411 (2001)

9. A. Trojanowska, [In:] A. Grzybek (ed.) Modelowanie energetycznego wykorzystania biomasy. Falenty-Warszawa. Wydawnictwo ITP, 76-82 (2010)

10. M. Labrecque, T. Teodorescu, BIOMASS BIOENERG 25, 135-146 (2003)

11. W. Nissim, F. Pitre, T. Teodorescu, M. Labrecque, BIOMASS BIOENERG 56, 361-369 (2013)

12. R. Kopp, L.P. Abramhamson, E.H. White, K.F. Burns, C.A. Nowak, BIOMASS BIOENERG 12(5), 313-319 (1997)

13. M. Weih, N.-E. Nordh, BIOMASS BIOENERG 23, 397-413 (2002)

14. W. Nowak, J. Sowiński, A. A. Jama, Fragmenta Agronomica 28(2), 55-62 (2011)

15. M. Stolarski, Agrotechniczne $i$ ekonomiczne aspekty produkcji biomasy wierzby krzewiastej (Salix spp.) jako surowca energetycznego (Wyd. UW-M, Olsztyn, 2009)

16. L. Styszko, D. Fijałkowska, M. Sztyma-Horwat, M. Ignatowicz, PAK, 5 512-515 (2010a)

17. L. Styszko, D. Fijałkowska, M. Sztyma-Horwat, ROCZ OCHR SR 12, 339-350 (2010b).

18. L. Styszko L., M. Ignatowicz, A. Borzymowska, Zeszyty Problemowe Postępów Nauk Rolniczych Z. 564, 237-245 (2011) 
19. J. Tworkowski, S. Szczukowski, M. Stolarski, Fragmenta Agronomica 27(4), 135-146 (2010)

20. M. Ignatowicz, L. Styszko, [In:] T.M. Traczewska (ed.) Interdyscyplitarne zagadnienia $w$ inżynierii $i$ ochronie środowiska, Oficyna Wyd. PW Wrocław, 203-212, (2013)

21. L. Styszko, D. Fijałkowska, Zeszyty Problemowe Postępów Nauk Rolniczych Z. 582, 73-80 (2015)

22. S. Szczukowski, J. Tworkowski, M. Stolarski, W. Fortuna, Fragmenta Agronomica 26(3), 146-1 (2009) 